\title{
PRODUKTIVITAS PERTANAMAN CAMPURAN RUMPUT UNGGUL DENGAN LEGUM LOKAL PADA LAHAN GALIAN C DI KABUPATEN KARANGASEM
}

\author{
Budiasa I K.M., I W. Wirawan., dan I W. Suarna \\ Lab.Tumbuhan Pakan, Fakultas Peternakan Universitas Udayana, Bali \\ Coresponding authors: mangkubudiasa@unud.ac.id
}

\begin{abstract}
ABSTRAK
Penelitian di laksanakan di kawasan Lahan Galian C di Kabupaten Karangasem dengan tujuan untuk meningkatkan produktivitas hijauan secara kuantitatif dan kualitasnya serta dapat tersedia secara berkelanjutan. Tumbuhan pakan merupakan salah satu potensi yang dapat dikembangkan pada lahan kritis sebagai upaya meningkatkan produktivitas lahan sehingga alih fungsi lahan ataupun eksploitasi lahan secara berlebihan yang berdampak negatif terhadap lingkungan dapat diminimalisir. Seperti halnya kawasan galian C, yang oleh masyarakat ditambang seluas-luasnya karena alasan kurang produktif meskipun penambangan tersebut tidak menjapat ijin oleh pemerintah setempat karena merupakan kawasan lindung dan serapan air. Percobaan akan menggunakan 2 jenis rumput unggul yakni Paspalum atratum dan Panikum maximum cv Trichogume, dan satu jenis legum lokal yang telah adaptif pada lingkungan setempat yakni Centrocema pubescens. Tujuan penelitian adalah untuk mendapatkan informasi tentang Produktivitas Pertanaman Campuran Rumput Unggul dengan Legum Lokal, baik dari aspek agronomis maupun aspek nutrisinya. Rancangan percobaan yang akan digunakan adalah rancangan acak kelompok (RAK) yakni 3 terdiri atas 3 kelompok sebagai ulangan dan 6 perlakuan sehingga akan terdapat 18 petak (18 unit penelitian). Variabel aspek agronomis yang diamati meliputi jumlah anakan/cabang, jumlah daun, tinggi tanaman, dan hasil hijauan segar.Hasil penelitian menunjukan pertumuhan Paspalum atratum yang ditanam secara monokutur lebih tinggidibanding rumput Panikum maximum, demikian juga ketika masing-masing ditanam bercampur dengan Centrocema pubescens. Pada pertanaman campuran kedua jenis rumput bersama Centrocema pubescens, pertumbuhan rumput Paspalum atratum lebih dominan dibanding rumput Panicum maximum.
\end{abstract}

Kata kunci: Paspalum atratum, Panikum maximum, Centrocema pubescens, lahan galian c, pertanaman campuran

\begin{abstract}
ABSTARCT
This research to be carried out in the dryland area at Karangasem Regency with the aim of increasing forage productivity quantitavely and in quality and also can be available sustainably. Feed plants are one of the potentials that can be developed on critical land as an effort to increase land productivity so that over land conversion or over exploitation of land that has a negative impact on the enviroment can be minimized. As well as the sand quarry area, which the community mines as wide as posible for reasons of less productive even though the mining doesn't get permission by the local goverment because it it a protected area and wear absorption. The experiment will use 2 types superior grass, namely Paspalum atratum and Panicum maximum $c v$ Trichogume, and one type of local legume that has been adaptive to the local enviroment, namely Centrocema pubescens. The purpose of research is to get information about Productivity of Paspalum atratum and Panicum maximum $\mathrm{Cv}$ Trichoglume Mixed Cropping with Centrocema pubescense, both from the argonomic and nutritional aspect. The experimental design that will be used is block design that consists of 3 groups as replication and 6 treatment, so that there will bw 18 plots (18 research unit). The results of study showed that the growth of grass in the Passpalum atratum monoculturally was better then Panicum maximum grass, as well as the nutrient content. Better growth also occurs in mixed Paspalum maximum grass planting with Centrocema pubescens compare to Panicum atratum with Centrocema pubescens. In the planting of the mixture of both types of grass with legume Centrocema pubescens it was concluded that, the types of grass of Paspalum atratum is more dominant than the Panicum maximum.
\end{abstract}

Keyword: Paspalum atratum, Panicum maximum, Centrocema pubescens, sand quarry, mixed cropping 


\section{PENDAHULUAN}

Program Upaya Khusus Percepatan Populasi Sapi dan Kerbau Bunting (Upsus Siwab) yang tertuang dalam Peraturan Menteri Pertanian RI Nomor 48/ Permentan/PK.210/10/2016, merupakan komitmen pemerintah dalam mengakselerasi percepatan swasembada sapi dan mewujudkan Indonesia mandiri dalam pemenuhan pangan asal hewan yang ditargetkan tercapai tahun 2026. Konsekuensi logis dari program Upsus Siwab adalah tersediannya hijauan pakan dalam jumlah yang cukup dengan mutu yang baik secara berkesinambungan.

Kendala yang terjadi dalam pengembangan hijauan pakan adalah meningkatnya alih fungsi lahan sehingga luasan penanaman semakin terhimpit, belum optimalnya pemanfaatan lahan, budidaya tanaman pakan unggul belum banyak dilakukan, dan belum tersedianya data yang cukup tentang berbagai jenis tanaman pakan yang potensial dikembangkan seperti halnya pada lahan perkebunan sesuai dengan jenis tanaman perkebunan dan ketinggian tempat (Suarna dan Suryani, 2014). Lahan pertanian yang semakin menyempit menyebabkan budidaya tanaman pangan lebih diprioritaskan daripada tanaman penghasil pakan seperti hijauan (Partama, 2013).

Pemanfaatan lahan untuk produksi hijauan pakan secara lebih intensif sesungguhnya dapat dilakukan pada lahan-lahan kritis, untuk menghindari persaingan dengan tanaman pangan maupun perkebunan (Budiasa, 2005). Salah satu lahan tersebut adalah lahan galian $\mathrm{C}$, yang umumnya kurang subur secara fisik, karena mengandung pasir dan bebatuan. Jenis hijauan yang tumbuh pada lahan galian $\mathrm{C}$ sebagian besar adalah rumput alami yang produksi maupun kualitasnya rendah, sedangkan jenis legume secara umum kualitasnya tinggi tetapi produksi secara kuantitatif masih terbatas. Upaya yang dapat dilakukan adalah dengan introduksi jenis rumput unggul yang dapat berasosiasi dengan jenis legum lokal yang telah adaptif di lokasi lahan galian $\mathrm{C}$ sehingga dapat meningkatkan produktivitas lahan seiring dengan meningkatnya produksi dan kualitas hijauan pakan yang dihasilkan, yang pada akhirnya meningkatkan produktivitas ternak masyarakat setempat. Kondisi tersebut sekaligus dapat mencegah upaya pemanfaatan lahan menjadi areal penambangan pasir dan batu secara keseluruhan.

Lahan galian C pasca ditambang adalah salah satu lahan kritis yang harus mendapatkan perhatian serius untuk dikonservasi. Dengan aktivitas penambangan yang dilakukan telah menyebabkan kerusakan fisik, kimia, dan biologis tanah. Aktivitas penambangan pasir dan batu dapat dilihat secara kasat mata telah menyebabkan kerusakan vegetasi, hidrologi dan juga mengakibatkan perubahan bentang alam pada kawasan tertentu.

Reklamasi lahan merupakan usaha untuk memperbaiki atau memulihkan kembali lahan yang rusak akibat penambangan, agar lahan tersebut dapat berfungsi secara optimal sesuai dengan kemampuannya. Kegiatan reklamasi memiliki 2 tahap yaitu: 1) tahap pemulihan yaitu pemulihan lahan bekas tambang untuk memperbaiki lahan yang terganggu ekologinya; dan 2) tahap pemanfaatan yaitu persiapan lahan bekas tambang yang sudah diperbaiki ekologinya untuk pemanfaatan selanjutnya. Usaha penghijauan lahan bekas tambang merupakan tindakan pemulihan dan pelestarian lingkungan, bila penghijauan disertai program penanaman tanaman pertanian, maka usaha tersebut berfungsi ganda yaitu selain pelestarian lingkungan juga peningkatan hasil.

Jarak tanam sangat penting diperhatikan untuk penanaman gamal pada lahan kritis dengan berbagai keterbatasan faktor-faktor tumbuh, terlebih lagi jika penanaman juga diarahkan pada tujuan konservasi lahan. Penanaman tumbuhan pakan adalah salah satu konservasi lahan yang mencakup metode vegetatif, sekaligus mekanik. Pengaturan jarak tanam dapat dipandang sebagai pembuatan bangunan-bangunan untuk pencegahan erosi serta manipulasi mekanik tanah dan permukaan tanah (Rahayu dan Heni, 2015)

Memcermati karakteristik dari lahan galian $\mathrm{C}$ pasca ditambang maka diperlukan jenis tanaman yang mampu tumbuh dengan baik pada lahan yang tergolong kritis tersebut. Jenis rumput unggul yang mampu tumpuh pada lahan kering diantaranya adalah Panikum maximum, dan Paspatum atratum, sedangkan jenis legum lokal yang yang telah adaptif pada beberbagai jenis lahan adalah Centrosema pubescens. Sistem penanaman yang tepat terutama terkait dengan jarak tanam sangat penting untuk diketahui, demikian juga upaya perbaikan kualitas lahan secara langsung maupun tidak langsung dengan pemanfaatan pupuk organik. Data-data ilmiah terkait produksi hijauan pada lahan kritis khususnya pada lahan galian $\mathrm{C}$ pasca ditambang juga masih sangat terbatas. Dengan demikian penelitian mengenai produksi beberapa jenis rumput unggul berasosiasi dengan legume lokal sangat penting untuk dilakukan.

\section{MATERI DAN METODE}

Penelitian dilaksanakan pada lahan galian $\mathrm{C}$ di wilayah Desa Sebudi, Kecamatan Selat, Kabupaten Karangasem, Bali. Bahan yang digunakan adalah bibit rumput Paspalum atratum, dan Panicum maximum cv. Trichoglume, dan legum Centrocema pubescens, pupuk organik berupa pupuk kotoran sapi. Sedangkan alat-alat yang digunakan dalam penelitian 
ini adalah timbangan dengan berbagai kapasitas dan kepekaan, $\mathrm{pH}$ meter untuk mengukur $\mathrm{pH}$ tanah, pita ukur, penggaris, kantong plastik dan amplof berbagai ukuran untuk koleksi sampel hijauan, serta gunting, sabit dan alat potong lainnya

Percobaan menggunakan rancangan acak kelompok (RAK). Perlakuan yang dicobakan terdiri atas pertanaman campuran dengan jarak tanam 25 $\mathrm{cm}$, antara 2 jenis rumput unggul yaitu Paspalum atratum dan Panikum maximum cv Trichoglume dengan 1 jenis legum lokal yakni Centrocema pubescens, sehingga akan terdapat 6 perlakuan. Percobaan dikelompokan menjadi tiga kelompok sebagai ulangan, sehingga percobaan ini terdiri atas $6 \times 3=18$ unit percobaan. Perlakuan tersebut adalah:

A. Rumput Paspalum atratum (monokultur)

B. Rumput Panicum maximum cv Trichoglume (monokultur)

C. Campuran rumput Paspalum atratum dengan Centrocema pubescens

D. Campuran rumput Panicum maximum cv Trichoglume dengan Centrocema pubescens

E. Campuran rumput Paspalum atratum dan Panicum maximum cv Trichoglume

F. Campuran rumput Paspalum atratum dan Panicum maximum cv Trichoglume dengan Centrocema pubescens

Selama penelitian dilakukan pemupukan dengan pupuk organik kotoran sapi dengan dosis 15 ton/ ha sebanyak satu kali yang diaplikasikan pada awal penelitian. Sampel tanah dari lokasi penelitian di analisis di laboratorium untuk mengetahui tingkat kesuburan dan karaktersistiknya, demikian juga dilakukan analisis terhadap pupuk organik yang akan digunakan untuk melakukan pemupukan pada percobaan ini.

Variabel yang diamati pada pelitian ini adalah aspek agronomis mencakup pertumbuhan dan produksi tanaman: 1) Tinggi tanaman (cm), diukur dengan penggaris atau pita ukur mulai dari pangkal tanaman sampai ujung batang yakni pada collar daun terakhir yang telah sempurna (pada rumput); atau dari pangkal tanaman sampai pucuk tertinggi (pada legum) yang diukur setiap minggu; 2) Jumlah anakan atau cabang, diukur setiap minggu dengan menghitung semua anakan (pada rumput) yang telah muncul kepermukaan tanah, sedangkan jumlah cabang dihitung pada tanaman legum; 3) Berat segar total hasil hijauan, batang, dan daun (g/rumpun), adalah berat segar total hijauan, batang, dan daun setelah dipotong pada akhir periode pertumbuhan (periode panen). Barat batang adalah berat bagian batang (culm) tanaman dengan pelepah daun, sedangkan berat daun yang dimaksud adalah hanya berat helaian daun.

\section{HASIL DAN PEMBAHASAN}

Penelitian ini diamati pada periode Gunung Agung di Karangasem Bali sedang meletus, sehingga mengakibatkan pertumbuhan rumput dan legume dapat dinyatakan terhambat karena permukaan daun terpapar abu letusan sehingga terdapat bagian tanaman yang mengalami kelayuan/mati sebelum waktunya untuk hasil panen pertama. Karena terjadi situasi dan kondisi tersebut, maka hasil tanaman yang disajikan yakni berat total, berat batang, dan berat daun adalah dalam bentuk segar. Selain dampak langsung dari abu vulkanik, situasi tersebut juga berpengaruh terhadap kondisi klimatologis lokasi penelitian, sehingga akan berpengaruh terhadap pertumbuhan tanaman seperti yang dinyatakan Suarna et al. (2018) bahwa produksi tumbuhan pakan sangat dipengaruhi oleh tipologi dan tataguna lahan serta kondisi klimatologis yang ada dikawasan tempat tumbuh tanaman.

Hasil dianalisis secara deskriptif, dan untuk membuktikan ada tidaknya pengaruh paparan abu vulkanik terhadap pertumbuhan dan hasil tanaman, maka panen dilakukan sebanyak dua periode dan kebetulan pada panen periode kedua tidak terjadi letusan sehingga tanaman tidak terpapar abu vulkanik akibat letusan Gunung Agung.

\section{Hasil Panen Pertama}

Hasil penelitian pada panen pertama menunjukan bahwa terdapat perbedaan pertumbuhan tinggi tanaman, jumlah daun, jumlah anakan/cabang, berat total, berat batang, berat daun, serta jumlah daun diantara perlakuan (Tabel 1).

Tabel 1 Pertumbuhan dan Produksi Pertanaman Campuran Rumput Unggul dengan Legum Lokal pada Lahan Galian C di Kabupaten Karangasem

\begin{tabular}{|c|c|c|c|c|c|c|c|}
\hline \multirow{2}{*}{$\begin{array}{c}\text { Per- } \\
\text { lakuan }\end{array}$} & \multirow{2}{*}{$\begin{array}{c}\text { Jenis } \\
\text { Tanaman }\end{array}$} & \multicolumn{6}{|c|}{ Variabel } \\
\hline & & $\mathrm{TT}$ & JD & $\mathrm{JA} / \mathrm{C}$ & BT & $\mathrm{BB}$ & $\mathrm{BD}$ \\
\hline $\mathrm{A}$ & Paspalum & 38 & 143 & 62 & 262,1 & 99,7 & 162,4 \\
\hline B & Panikum & 61 & 211 & 51 & 103,1 & 61,5 & 41,6 \\
\hline \multirow[t]{2}{*}{$\mathrm{C}$} & Paspalum & 47 & 124 & 55 & 422 & 189,5 & 232,5 \\
\hline & Centrocema & 108 & 49 & 9 & 22,3 & 8,6 & 13,7 \\
\hline \multirow[t]{2}{*}{$\mathrm{D}$} & Panikum & 57 & 170 & 50 & 116,1 & 74,2 & 41,9 \\
\hline & Centrocema & 87 & 59 & 14 & 28,3 & 10,9 & 17,4 \\
\hline \multirow[t]{2}{*}{$\mathrm{E}$} & Paspalum & 47 & 88 & 43 & 228,2 & 102,6 & 125,6 \\
\hline & Panikum & 54 & 84 & 24 & 42,1 & 25 & 17,1 \\
\hline \multirow[t]{3}{*}{$\mathrm{F}$} & Paspalum & 49 & 71 & 35 & 228,1 & 102,9 & 125,2 \\
\hline & Panikum & 48 & 78 & 24 & 40,8 & 24,4 & 16,4 \\
\hline & Centrocema & 91 & 21 & 14 & 15,9 & 7,4 & 8,5 \\
\hline
\end{tabular}

Keterangan: TT= Tinggi tanaman $(\mathrm{cm})$; JD=Jumlah daun; JA/C=Jumlah Anakan/ cabang; $\mathrm{BT}=$ Berat total (g/rumpun); $\mathrm{BB}=$ Berat Batang ( $\mathrm{g} /$ rumpun); $\mathrm{BD}=$ Berat daun ( $\mathrm{g} /$ rumpun)

Rumput Paspalum atratum yang ditanam secara monokultur mempunyai tinggi yang relatif lebih rendah dibandingkan dengan yang ditanam secara campuran, sedangkan rumput Panikum maximum 
terjadi hal yang sebaliknya. Hal yang sama terjadi terhadap berat total hijaun rumput Paspalum atratum yang ditanam secara monokultur mempunyai berat yang relatif lebih rendah dibandingkan dengan yang ditanam secara campuran, sedangkan berat total hijauan rumput Panikum maximum yang ditanam bercampur dengan rumput Paspalum atratum (perlakuan $\mathrm{E}$ dan F) relatif lebih rendah dibanding yang ditanam secara monokultur maupun campuran dengan Centrocema pubescens.

Produksi daun rumput $P$. atratum relatif lebih tinggi dari produksi bagian batang pada semua perlakuan baik yang ditanam secara monokultur maupun campuran, sedangkan rumput $P$. maximum terjadi sebaliknya. Dengan demikian secara kualitas jenis rumput $P$. atratum dapat diduga lebih baik dibanding rumput $P$. maximum karena dengan produksi daun yang lebih tinggi daripada batang maka kandungan proteinnya akan semakin tinggi.

Produksi hijauan tertinggi dihasilkan pada perlakuan pertanaman campuran rumput $P$. atratum dengan C.pubescens yakni sebesar 444,3 g dan terendah dihasilkan pada penanaman rumput $P$. maximum secara monokultur yakni sebesar 103,1 gram. Pertanaman campuran $P$. atratum dengan C.pubescens dengan jarak tanam $25 \mathrm{~cm}$ dapat menghasilkan produksi hijauan segar sebesar 17,77 ton/ha untuk satu kali panen, sedangkan jika ditanam secara monokutur meskipun produksi per rumpun relatif lebih rendah yakni sebesar 262,1 g, akan tetapi jika dihitung produksi per hektar maka produksinya adalah sebesar 41,94 ton/ha dalam satu kali panen. Akan tetapi hasil yang lebih tinggi tersebut, tidak serta merta dapat digunakan untuk menarik kesimpulan bahwa pertanaman secara monokultur lebih baik dibandingkan dengan pertanaman campuran, mengingat fungsi $C$. pubescens merupakan jenis legume yang mempunyai kualitas nutrient lebih baik dibanding jenis rumput dan juga mempunyai kemampuan meningkatkan kesuburan tanah melalui fiksasi nitrogen (N). Demikian juga karena hijauan yang lebih beragam menunjukan kualitas yang lebih baik jika dibandingkan dengan satu jenis hijauan.

\section{Hasil Panen Kedua}

Hasil penelitian pada panen kedua menunjukan bahwa terdapat perbedaan pertumbuhan tinggi tanaman, jumlah daun, jumlah anakan/cabang, berat total, berat batang, berat daun, serta jumlah daun diantara perlakuan dengan perbandingan hasil antar perlakuan yang sama dengan hasil pada panen pertama, akan tetapi secara kuantitatif hasilnya lebih tinggi untuk semua variabel pada semua perlakuan (Tabel 2). Hasil penelitian menunjukan hasil Centrocema pubescens pada pertanaman campuran dengan rumput Paspalum atratum dan Panicum maximum $\mathrm{cv}$ Trichloglume adalah paling rendah, hal ini dapat disebabkan karena kompetisi terhadap faktor tumbuh terutama sinar matahari.

Tabel 2 Pertumbuhan dan Produksi Pertanaman Campuran Rumput Unggul dengan Legum Lokal pada Lahan Galian C di Kabupaten Karangasem

\begin{tabular}{|c|c|c|c|c|c|c|c|}
\hline \multirow{2}{*}{$\begin{array}{l}\text { Per- } \\
\text { lakuan }\end{array}$} & \multirow{2}{*}{$\begin{array}{c}\text { Jenis } \\
\text { Tanaman }\end{array}$} & \multicolumn{6}{|c|}{ Variabel } \\
\hline & & $\mathrm{TT}$ & JD & $\mathrm{JA} / \mathrm{C}$ & BT & $\mathrm{BB}$ & $\mathrm{BD}$ \\
\hline $\mathrm{A}$ & Paspalum & 54 & 154 & 76 & 290,1 & 109,5 & 180,4 \\
\hline B & Panikum & 64 & 277 & 71 & 152,4 & 90,5 & 61,4 \\
\hline \multirow[t]{2}{*}{$\mathrm{C}$} & Paspalum & 52 & 148 & 75 & 524,6 & 229,3 & 274,2 \\
\hline & Centrocema & 115 & 57 & 11 & 26,4 & 9,3 & 15,7 \\
\hline \multirow[t]{2}{*}{$\mathrm{D}$} & Panikum & 58 & 181 & 73 & 147,2 & 94,2 & 51,9 \\
\hline & Centrocema & 77 & 54 & 12 & 26,3 & 10,4 & 15,2 \\
\hline \multirow[t]{2}{*}{$\mathrm{E}$} & Paspalum & 56 & 126 & 62 & 272,6 & 128,6 & 143,2 \\
\hline & Panikum & 52 & 97 & 29 & 48,1 & 27,2 & 19,5 \\
\hline \multirow[t]{3}{*}{$\mathrm{F}$} & Paspalum & 54 & 123 & 56 & 299,3 & 132,7 & 165,3 \\
\hline & Panikum & 57 & 89 & 26 & 51,8 & 29,6 & 21,2 \\
\hline & Centrocema & 102 & 28 & 17 & 16,9 & 7,2 & 8,4 \\
\hline
\end{tabular}

Keterangan: TT= Tinggi tanaman $(\mathrm{cm}) ; \mathrm{JD}=\mathrm{Jumlah}$ daun; JA/C=Jumlah Anakan/ cabang; $\mathrm{BT}=$ Berat total ( $\mathrm{g} /$ rumpun); $\mathrm{BB}=$ Berat Batang ( $\mathrm{g} /$ rumpun); $\mathrm{BD}=$ Berat daun ( $\mathrm{g} /$ rumpun)

Perbedaan hasil panen pertama dengan panen kedua tersebut dapat diduga karena berdasarkan kondisi dilapangan pada periode pertumbuhan untuk panen kedua tidak terjadi periode letusan sehingga tanaman rumput maupun legume tidak terpapar abu vulkanik, sehingga proses pertumbuhan, perkembangan dan proses-proses fisiologi tanaman terutama fotosintesis dapat berlangsung dengan normal. Pertumbuhan rumput Panikum maximum cv Trichoglume relatif lebih rendah dibanding rumput Paspalum atratum pada semua perlakuan, berbeda dengan yang dinyatakan Roni, et al. (2016) yang melaporkan bahwa Panicum maximum cv Trichoglume tumbuh lebih tinggi, dengan jumlah daun dan anakan yang lebih banyak dibanding rumput Setaria splendida, dan Pennisetum purpureum. Jenis rumput Panicum maximum sesungguhnya sudah sangat adaptif diberbagai daerah khususnya Bali, sesuai yang dilaporkan Suyasa, et al. (2016) bahwa rumput Panicum maximum adalah salah satu jenis hijauan yang sudah biasa diberikan kepada sapi di Desa Belangan, dan tersedia pada musim hujan maupun kemarau.

\section{SIMPULAN DAN SARAN}

Dari hasil penelitian dapat disimpulkan bahwa hasil hijauan rumput Paspalum atratum lebih tinggi dari rumput Panikum maximum maupun legume Centrocema pubescens, sehingga dapat dinyatakan rumput Paspalum atratum lebih 
dominan pertumbuhan dan hasilnya baik pada sistem monokultur maupun pertanaman campuran. Hasil panen legume Centrocema pubescens paling rendah pada pertanaman campuran dengan rumput Paspalum atratum dan Panicum maximum, dibandingkan dengan pertanaman campuran hanya dengan Paspalum atratum, atau Panicum maximum. Disarankan perlu dilakukan penelitian yang dapat mengukur dan menganalisis secara menyeluruh dari sistem pertanaman monokultur maupun pertanaman campuran pada tumbuhan pakan, sehingga tidak didasarkan hanya dengan hasil panen.

\section{UCAPAN TERIMA KASIH}

Ucapan terima kasih disampaikan Kementerian Ristekdikti RI, dan Rektor Universitas Udayana melalui Lembaga Penelitian dan Pengabdian kepada Masyarakat atas pendanaan yang diberikan melalui DIPA PNBP Universitas Udayana T.A 2018.

\section{DAFTAR PUSTAKA}

Budiasa I K.M. 2005. Ketersediaan hijauan sumber pakan sapi bali berdasarkan penggunaan lahan dan topografi berbeda di Kabupaten Jembrana Provinsi Bali. Tesis. Sekolah Pascasarjana Institut Pertanian Bogor, Bogor.

Partama, I.B.G. 2013. Nutrisi dan Pakan Ternak Ruminansia. Udayana University Press
Rahayu A.P., dan N. Heni. 2015. Konservasi Lahan dengan Hijauan Pakan Ternak. Direktorat Pakan, Direktorat Jenderal Peternakan dan Kesehatan Hewan Kementerian Pertanian Indonesia (www. pakan.ditjennak.pertanian.go.id)

Roni, N.G.K., N.M. Witariadi., N.W. Siti, dan I G. Suranjaya. 2016. Pertumbuhan Kembali dan Produksi Beberapa Jenis Rumput yang Diberi Pupuk Organik. Pastura. J. of Tropical Farage Science. Vol. 5 No. 2 (83-87).

Suarna, I W., dan N. N. Suryani. 2014. Potensi dan Pengembangan Tanaman Pakan pada Lahan Perkebunan di Kabupaten Gianyar Provinsi Bali. Makalah Seminar Nasional Himpunan Ilmuwan Tumbuhan Pakan Indonesia (HITPI). Denpasar, Bali.

Suarna, I.W., dan I K.M. Budiasa. 2016. Pengaruh Pupuk organik terhadap produksi dan kualitas hijauan pastura campuran pada lahan kering di Desa Sebudi Karangasem. Majalah Ilmiah Peternakan. Vo. 19 No. 3.

Suarna, I W., N. N. Suryani., dan I K.M. Budiasa. 2018. Potensi dan Adaptasi Tumbuhan Pakan Alysicarpus vaginalis di Provinsi Bali. Pastura. $J$. of Tropical Farage Science. Vol. 8 No. 1 (10-12). Suyasa N., N.L.G. Budiari, dan I.A.P. Parwati. 2016. Memanfaatkan Ketersediaan Hijauan Pakan Ternak (HPT) Dalam Berbagai Komposisi Pakan untuk Menjaga Produktivitas Sapi Bali (Studi Kasus di Desa Balanga, Bangli). Pastura. J. of Tropical Farage Science. Vol. 5 No. 2 (109-113) 